Island Studies Journal, Vol. 6, No. 1, 2011, pp. 59-86

\title{
Participatory Action Research for Dealing with Disasters on Islands
}

Ilan Kelman

Center for International Climate and Environmental Research

Oslo, Norway

Contact through www.ilankelman.org/contact.html

James Lewis

Datum International, $U K$

jameslewis@datum-international.eu

JC Gaillard

University of Auckland, New Zealand

jc.gaillard@auckland.ac.nz

and

Jessica Mercer

Oxfam Australia, East Timor

jessica-mercer@hotmail.com

\begin{abstract}
Much disaster research has a basis in non-island case studies, although monodisciplinary disaster-related research across past decades has often used case studies of individual islands. Both sets of work contribute to contemporary 'participatory action research' which investigates ways of dealing with disasters on islands. This paper asks what might be gained through combining disaster research, island studies, and participatory action research. What value does island studies bring to participatory action research for dealing with disasters? Through a critical (not comprehensive) overview of participatory action research for dealing with disasters on islands, three main lessons emerge. First, the island context matters to a certain degree for disaster-related research and action. Second, islandness has much more to offer disaster-related research than is currently appreciated. Third, more studies are needed linking theory to evidence found on the ground on islanders' terms. Limitations of the analyses here and future research directions are provided.
\end{abstract}

Keywords: disaster risk reduction, islandness, participatory action research, resilience, scale, vulnerability

(C) 2011: Institute of Island Studies, University of Prince Edward Island, Canada.

\section{Disaster Research and Islands}

When examining the history of empirical work in disaster research, focusing on disasters as social rather than natural phenomena, most case studies in the literature are not on, or about, islands. Amongst the minority of researchers examining disasters over past decades 
who did use island case studies, the trend is mono-disciplinary work. Nonetheless, that work has provided a solid and needed foundation for developing disaster studies that are less disciplinary and more reflective of islands as places.

Place-based geography for hazards, risk, vulnerability, and disasters has long been established (e.g. Hewitt \& Burton, 1971) and is a core ethos behind island-based disaster research (e.g. Gaillard, 2007; Le Masson \& Kelman, 2011; Lewis, 1999; Mercer et al., 2009). One methodology that has been increasingly used is "participatory action research", emerging from international development studies. It seeks to involve research subjects in solving problems that they identify affecting their communities. One such problem is dealing with disasters.

In examining all these areas - disaster research, island studies, and participatory action research - is anything gained through their combination? In particular, what value (if any) does island studies (see also Baldacchino, 2006; Depraetere, 2008; McCall 1994, 1996) bring to participatory action research for dealing with disasters?

The objective of this paper is to explore these questions through a critical (though not comprehensive) overview of participatory action research for dealing with disasters on islands.

The rest of Section 1 summarizes the recent history of research on disaster-related topics, with particular attention paid to island case studies. Section 2 defines and illustrates participatory action research for dealing with disasters. Islandness is almost absent from that discussion, leading to an overview of island studies with respect to this topic in Section 3. Discussion and analysis are provided in Section 4 through recommending future directions that such work should pursue. Finally, conclusions summarize the ideas that have emerged in the overview, providing recommendations on how to improve and better understand participatory action research for dealing with disasters on islands.

\section{Disaster research}

Humanity has for centuries sought to explain and understand calamity. In considering Western scientific thought and method, some highlights tend to be emphasized, although focusing on those sources leave the story far from complete (see further background in Gaillard, 2007, 2010; Hewitt, 1983, 1997; Lewis, 1999; Wisner et al., 2004).

For instance, Rousseau (1756) is often hailed as one of the first Western thinkers to formally question whether or not disasters were inevitable. He reacted to the devastating 01 November 1755 earthquake and tsunami disaster in Lisbon, Portugal, by writing to Voltaire, questioning humanity's role in creating that disaster. Rousseau (1756) described how nature did not construct the houses which failed in the earthquake, killing people. Nor did nature develop Lisbon to such a high population density that exacerbated the death toll. He further explained how many fatalities occurred because people behaved inappropriately after the initial shaking, leaving them exposed to further shaking and the tsunami. 


\section{Islands}

Rousseau's (1756) principle was that society would be little affected by an earthquake occurring in the wilderness.

These ideas were infrequently explored until the $20^{\text {th }}$ century. Prince (1920) represented a pioneering social study of disasters inducing social change, by focusing on the 1917 Halifax harbour explosion. Studies in following years (e.g. Carr, 1932) led up to White (1942/1945) examining flood disasters in the USA from a people, rather than a nature, behaviour perspective. He proposed a range of 'adjustments' to human behaviour to be adopted for reducing flood damage. These adjustments went beyond the standard, embedded approach of government action controlling water in order to "protect" the population from flooding.

The following decades saw increasing numbers of sociological and geographical studies, particularly from North America and the UK, helping to develop a field of disaster research. Many key disaster research theories were born in this period, such as convergence theory (Fritz \& Mathewson, 1957) referring to a spontaneous movement of goods, people, and information-both organized and unorganized-towards a disasteraffected area.

The 1970's witnessed a formal intersection of disaster studies with ongoing work in international development. That was spurred by some specific disasters such as the Sahel drought (e.g. Comité d'Information Sahel, 1975; Copans, 1975) and earthquakes in Central America. For the latter, O'Keefe et al. (1976) implicated human behaviour in all "natural disasters". They identified "the growing vulnerability of the population to extreme physical events" (ibid.: 566), not changes in nature, as causing the observed increase in disasters. The 4 February 1976 Guatemala earthquake disaster had epitomized that situation.

Since the 1980's, there has been a rapid expansion of disaster research across numerous disciplines. Tertiary teaching centres were created, specialised degree programmes started, and many disaster-related journals were founded, complementing the few that already existed.

Some literature remained locked in technocratic paradigms of nature causing disasters; hence humanity must control nature to deal with disasters. Without denying nature's input, other authors used field experience and theoretical analyses to supersede that viewpoint, showing that, to understand disasters, it is crucial to understand human decisions over the long-term which form a process creating, maintaining, and perpetuating vulnerability, from past to present and into the future (e.g. Hewitt, 1983, 1997; Lewis, 1999; Wisner et al., 2004).

Disasters and hazards are not exogenous forces to be separated from a place and 'protected' against by one-off, individual efforts. Instead, hazards and especially vulnerability are integral to day-to-day life and livelihoods. They must be tackled regularly on a community basis in order to reduce disaster risk over the long-term. Many practitioners accept that evidence, recognizing that nature does not cause disasters; it is thus necessary to deal with human beings and communities on their own terms in order to 
tackle disasters (e.g. Anderson \& Woodrow, 1989; Global Network of Civil Society Organizations for Disaster Reduction, 2009).

\section{Disaster research and islands}

Throughout the evolution of disaster research, when looking at the case studies used by research groups and centres, only one earlier group explicitly recognized the advantages of studying islands: the Bradford Disaster Research Unit (www.ilankelman.org/bdru.html, with Gane, 1975 and O'Keefe \& Conway, 1977 as examples). This unit was founded at the Project Planning Centre, University of Bradford, UK, in the 1970's by the head of the Project Planning Centre, Michael Gane, and James Lewis supported by the Leverhulme Trust.

The unit specifically did not adopt a particular discipline or set of disciplines, focusing instead on understanding how to prevent disasters before they happened. With work in the Pacific and the Caribbean complementing studies on disasters in the UK and general reviews, this work paved the way for exploring disasters in the context of island vulnerability. Numerous island and disaster studies existed alongside this work, mostly from mono-disciplinary perspectives but only occasionally explicitly engaging with the place-based notion of an island.

Work by anthropologists on disasters affecting islands dates back several decades. Examples from the 1950's are the cultural effects of volcanic eruptions and typhoons among traditional Pacific societies (e.g. Belshaw, 1951; Firth, 1959; Keesing, 1952; Schneider, 1957; Spillius, 1957). Formerly hidden within the literature of their discipline, many of these references reveal intrinsic and innate resilience within island-based communities where hazards were part of normal life. 'Disasters', if locally recognized as such, went unknown in and unaided from the wider world. These insights were published and accepted within the mono-disciplinary literature long before 'resilience' and 'vulnerability' became popular terms to the extent of now being accused of overuse and misuse in much contemporary literature, especially climate change studies (Baldacchino, 2004; Gaillard, 2010; Lewis \& Kelman, 2010; Mercer, 2010).

Similarly, geography has a long history covering this topic. For example, in the 1970's, McLean et al. (1977) studied cyclones affecting Fiji, with Baines \& McLean (1976) reporting on cyclone impacts on Funafuti atoll, Tuvalu. Meanwhile, Adams (1978-1979) described Hurricane Janet affecting one island of the Grenadines as part of a place-based description of that island.

Throughout the decades, physical sciences have published numerous pieces on hazards across islands, including catalogues and explanations of earthquakes (e.g. Angenheister, 1921; Patterson, 1977), tsunamis (e.g. Keys, 1963), volcanoes (e.g. Baker, 1968; Hovey, 1903), and storms (e.g. Kerr, 1976). These were legitimate studies of physical phenomena that happened to affect island locations. They had, at best, limited interaction with other social sciences. 


\section{Islands}

Overall, islands have long been a part of the evolution of disaster research. Yet, apart from scattered exceptions (as noted above, plus see for instance Campbell, 1984 and Lewis, 1981), little work has explored islandness or island places within the context of vulnerability, risk, and disasters, even when the case studies involved islands. That is starting to change with the melding of participatory action research and disaster risk reduction research and practice.

\section{Participatory Action Research for Disaster Risk Reduction}

In the 1970's, development studies started examining long-term causes of disasters, focusing on human behaviour and decisions leading to a process of creating (in the past and present), maintaining (in the present), and perpetuating (into the future) vulnerability. Since the 1980's, development studies has come to the forefront of applying the knowledge generated. The approach taken was not driven solely by curiosity, as was much earlier work, and was rarely defined by a single discipline. Instead, it involved active collaboration with the people and communities as the research participants in order to galvanize action on their terms to deal with the problem identified (Chambers, 1994; Cornwall \& Jewkes, 1995).

This approach and specific techniques within it has many labels, a contemporary common one of which is "participatory action research" (e.g. Wisner et al., 1991). The words highlight respectively that (i) the research subjects are full participatory partners in the work of trying to solve a problem, (ii) action to solve the problem needs to arise from the work, and (iii) original science, i.e. research, is still being produced. One of the development problems identified for solving is dealing with disasters. Participatory action research is increasingly being used - and critiqued, because no approach is perfect - to determine and apply how vulnerability could be reduced over the long-term, using case studies of islands.

A specific example illustrates participatory action research for dealing with disasters on islands and wider questions surrounding its implementation. Figure 1 depicts a house in a rural part of Upolu, Samoa, with the photo taken a few weeks after the house was said to have been damaged by Cyclone Heta in 2004. Many suggestions could be made to try to avoid similar damage from recurring.

Architectural approaches would suggest tying the roof to the walls, preferably with local materials (Aysan \& Davis, 1992). Sociological approaches might invoke Marx (1887) who described power structures and political processes which, in a modern academic context, can be interpreted as leaving less affluent people more vulnerable. Geographers might look at the location and, knowing that cyclones occur there, analyse how the home's location and design should be improved to be best suited for the hazards experienced in that place. None of these approaches is satisfactory on its own. The set of approaches needs to be applied in combination to generate as full a picture as possible of the situation and its solution. 


\section{Figure 1: A house on Samoa said to have been damaged by Cyclone Heta in 2004 (photo by Ilan Kelman).}

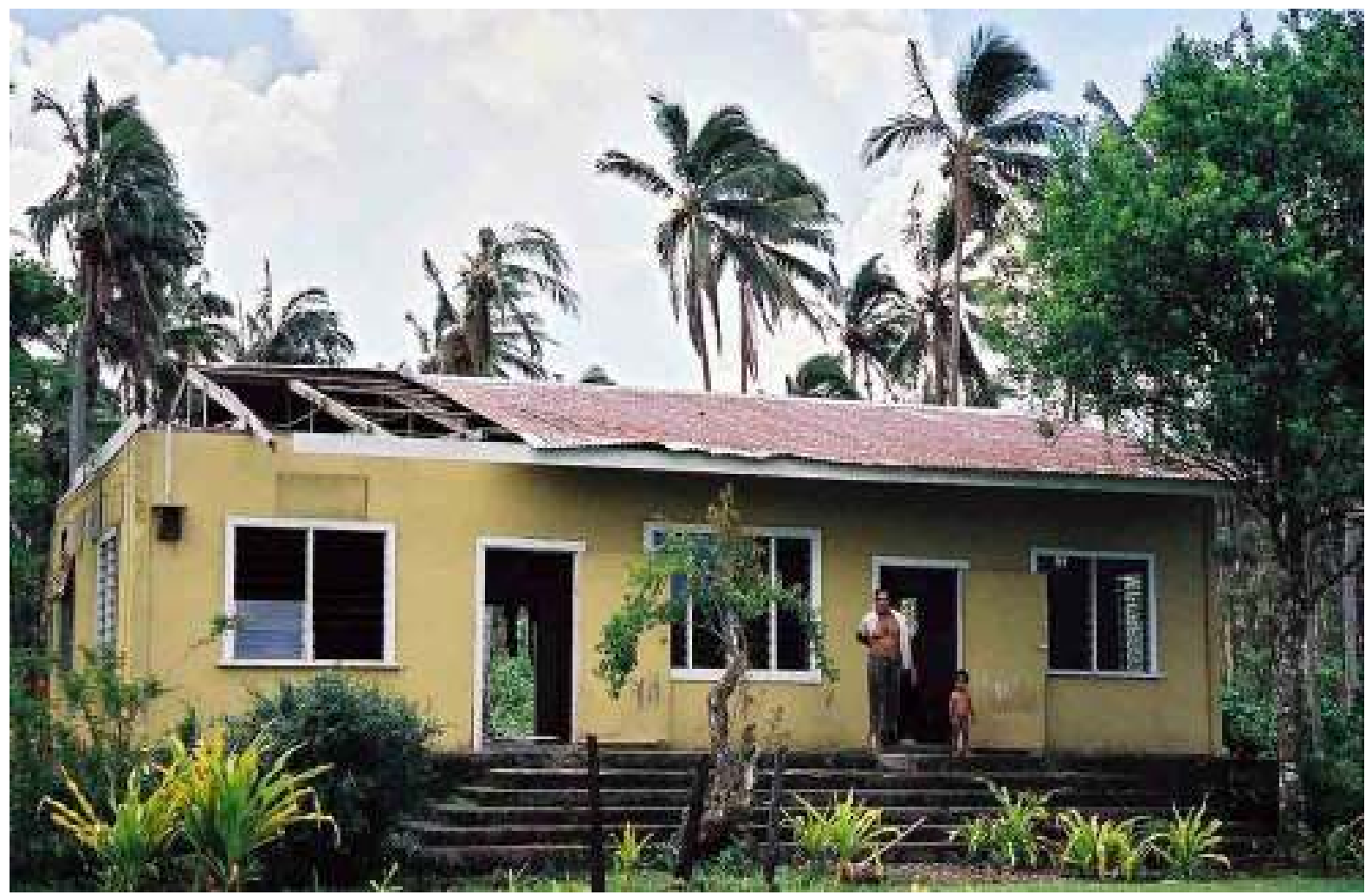

Participatory action research would determine the individual and collective choices that the occupants and the occupants' communities make within the web of local, national, regional, and international influences that created and continue to perpetuate a long-term situation of vulnerability. "Community" (and lack thereof, e.g. Walmsley, 2006) at all scales is incorporated, from the occupants' neighbours to the national government and international institutes. Decisions over all time scales are also included, from day-to-day acquisition of food to century-to-century decisions of where to live. This wide, multi-scalar situation is exposed by a single cyclone damaging the particular roof shown in Figure 1.

To a large degree, this situation is relatively contemporary. The house in Figure 1 is not a traditional dwelling and it is relatively uncommon across Samoa even amongst nontraditional houses. Traditionally, damaging storms would have often been factored into a dwelling's construction; and, if damage occurred, it would be put right immediately, often communally and with local resources (Firth, 1959; Spillius, 1957).

Traditional roofs were often removed as a storm approached, because they were constructed with that purpose in mind, and used as shelter on the ground (Campbell, 1984, 2006). In Samoa, traditional dwellings with raised floors and minimal permanent sidewalls offered the least resistance to and most structural security from storms and floods (Blake, 1993; Duly, 1979; Rapoport, 1969). Consequently, occupants and communities 
would not always have used imported materials for imported designs, as in Figure 1. Meanwhile, several weeks would not usually have been required for repair, also as in Figure 1.

This discussion does not claim that traditional approaches are a panacea nor that they are superior to all external interventions. Many situations involving traditional approaches led to worse circumstances than Figure 1 . For instance, in the $14^{\text {th }}$ century, regional cooling, sea-level decline, and likely increased storminess appears to have severely affected many Pacific island societies, inducing major disaster-related stresses on the population and consequent, significant cultural changes (Nunn, 2003).

Discussion of the Samoa example also does not claim that participatory action research would necessarily lead to a solution involving traditional dwellings. Samoans include a widely dispersed international population who frequently send remittances back to their relatives remaining on Samoa (Ahlburg, 1991; Connell \& Brown, 2005). In some circumstances, contact with those relatives leads to a taste for living conditions and consumables that are seen as being "modern", "developed", and "affluent", such as the house in Figure 1. That might lead to the expectation that aid, from remittances or other external sources are responsible for repairing the house. That expectation might come from the family living on Samoa, from their expatriate relatives, or from Samoan and/or international authorities.

No intimation is made that this specific family feels that way. The example merely illustrates that when enacting participatory action research, should the participants be only those affected on the island? Or should participants include overseas islanders and others involved in post-disaster or pre-disaster assistance?

The answer from the literature quoted throughout this paper clearly illustrates that successful participatory action research involves many people in different locations. Cronin et al. (2004b) in the Solomon Islands and Daly et al. (2010) in Samoa each included national government representatives and external participants in their participatory action research. A balance must be sought between (i) having too many people or too many resources used for participation and (ii) ensuring that a variety of perspectives is considered for the participation.

Rather than relying on one focus, one discipline, one knowledge base, one group of people, or one technique, a combination and balance is needed for dealing with disasters on islands. The focus of solving the problem is action, in order to try to improve the situation so that the occupants in Figure 1 do not experience similar vulnerability or damage in the future. That ought to be achieved, not just by researchers or practitioners, but also by the occupants themselves and their communities.

The ethos behind participatory action research, involving consultation and participation processes, is not for researchers to adopt the responsibility of improving each individual's and family's life. Instead, if individuals, families, communities, and institutions including governments are interested in improving, or could be convinced to improve, then 
researchers and practitioners can use participatory action research to facilitate, support, and assist the parties' own actions.

This approach to disaster research has been used globally (e.g. Lane et al., 2011), as well as on islands (e.g. Maceda et al., 2009). However, throughout the above discussion of participatory action research, the relevance of islands and islandness has not been made explicit, although an apparent relevance does emerge due to the number of studies using islands along with the island-based research that has often pioneered the techniques. To explore this matter further, the next section provides some examples of island case studies from the past few decades along with ongoing, contemporary work.

\section{Island Case Studies}

The examples in this section show how island case studies have led work in participatory action research for disaster risk reduction. No claim is made that these examples, or that island examples, are the only case studies available. Island work has, however, led this field, often piloting techniques and setting the stage for expansion into non-island case studies.

\section{Sea-level rise conference in 1989}

One of the earlier instances of participatory action research for dealing with disasters on islands was the 1989 sea-level rise conference in the Maldives, the archives of which are available at: www.islandvulnerability.org/s/r1989.html. The conference brought together scientists, both islanders and non-islanders, along with many non-scientist and often indigenous islanders, including politicians and decision makers. The discussion deliberately integrated science, policy, and practice on the islanders' terms to address the identified problem of sea-level rise.

The conference led to the Male Declaration on Global Warming and Sea Level Rise. That declaration painted a scenario of a global average temperature rise of $1-2^{\circ} \mathrm{C}$ by 2030 , expressed the difficulties that sea-level rise was expected to pose for small island states, and exhorted the more affluent countries to share resources with less affluent countries including technology, funds, and training assistance to address climate change. Many of these calls continue today (e.g. AOSIS, 2009).

An early expression of participatory action research during the conference was the initiation of AOSIS (Alliance of Small Island States) by representatives of Small Island Developing States (SIDS) ${ }^{1}$ in order to lobby internationally for climate change action. Since the 1989 conference, little has changed fundamentally in the SIDS' needs and calls for action on this topic.

\footnotetext{
${ }^{1}$ Currently, SIDS comprise 52 countries and overseas territories in tropical and low-latitude sub-tropical latitudes. They include Nauru, St. Dominica and Guinea-Bissau. SIDS are identified as having numerous common sustainability and development challenges, including disaster risk reduction (UN, 1994, 2005).
} 


\section{Islands}

From that conference, Lewis (1989a, 1989b, 1990a, 1990b, 1990c) published some of the earliest scientific papers on low-lying atolls and sea-level rise. One importance of those publications lies in highlighting the island context for an externally created vulnerabilityin that SIDS peoples have contributed negligibly to climate change-while promoting the islanders' views of the challenges. This work was specifically operational, seeking action, but nonetheless resulted in cutting-edge and pioneering scientific publications.

\section{Participatory mapping}

The use of three-dimensional maps as a participatory action research technique evolved from the experience in their application for vulnerability identification and reduction on islands in the Philippines and Indonesia (Gaillard \& Maceda, 2009). This work exemplifies how an island population's relative smallness and social compactness can bring forth a relatively rapid analysis by the islanders using basic and locally available materials combined with their energy and creativity.

Maceda et al. (2009), as one example, document the integration of Participatory 3Dimensional Maps (P3DM) into Community-Based Disaster Risk Reduction (CBDRR). The case study is Divinubo, an islet located off the island of Samar on the Pacific edge of the Philippine archipelago, which had a population of 703 in 2000. The P3DM methodology proved to be useful by facilitating much of the population to participate, by raising people's awareness of their own location and population, by allowing the mapping of assets and dangers, by better embedding CBDRR into day-to-day sustainability and development processes, and by being comparatively low-cost to set up and run.

In this respect, it is often the process of participatory action research that is more important than the final result (which in this case is the 3D map). The process of developing the map resulted in the above outcomes through giving islanders a voice and through enabling exchange amongst those who might otherwise not interact. Neither the scientists nor islanders were able to achieve the best results on their own. Collaboration, by bringing together different perspectives and knowledge types through participatory action research, was needed to achieve the desired result for disaster risk reduction.

P3DM as a tool and method within participatory action research is now being pursued for integrating disaster risk reduction, environment management, and development, again with islands as the pilot case studies, such as Cape Verde and Kiribati (Gaillard \& Cadag, 2010). When combined with other participatory action research approaches such as ranking, scoring, and Venn diagrams, P3DM facilitates the involvement of a large array of participants in addition to the islanders. Examples are government staff, NGO members, business owners, and scientists - any of whom might be from the island or not. It thus enables the integration of numerous knowledge and wisdom types as well as bottom-up and top-down actions. 
The importance of maps for communicating disaster risk reduction was shown in an island context by Haynes et al. (2007) working on volcano-affected Montserrat. With detailed features of the small island easily represented in a single small map, although not participatory in their making, different mapping forms were tested to see which was easiest for the population to understand: (i) Top-down, flat, plan view maps with contour lines which are usually used by scientists; (ii) three-dimensional computer-generated maps giving oblique perspectives of the island; and (iii) aerial photographs also giving an oblique perspective. Montserratians were least able to relate to plan view maps, with some improvement shown for the three-dimensional maps. In terms of orienting themselves and identifying key features of their home, the photographs were far superior to either of the maps.

\section{Combining knowledge types}

In Papua New Guinea (PNG), Mercer et al. (2009, 2010) formalized a method for using participatory action research to combine different knowledge types for disaster risk reduction. They detail the importance of the island context in bringing together local, indigenous knowledge from each of three case study villages with external scientific knowledge that was input into the villages. A framework was developed for applying participatory action research to engage communities in disaster risk reduction approaches based in their own knowledge, interests, and experiences but without neglecting wider contexts (Mercer et al., 2010). That framework was applied within the communities of Kumalu, Singas, and Baliau in PNG through techniques such as developing hazard timelines and pair-wise ranking to prioritize concerns and solutions (Mercer et al., 2009).

Whilst the final outputs-for instance, the hazard timelines-were in themselves important, it is often the discussion surrounding the types and uses of participatory action research techniques which generates the most results in terms of 'participation', 'action' and 'research'. That is, as is often heard in other development contexts, the process is more important than the product. This situation can make it challenging to analyse the outcomes of participatory action research, hence it is important that the full process is documented, along with the outputs and products.

In this manner, Singas identified internal and external influences affecting their flood hazards and flood vulnerabilities (Mercer \& Kelman, 2008) whilst Baliau learned to live with an erupting volcano (Mercer \& Kelman, 2010). Using those experiences, the step-bystep framework was modified to account for the islanders' recommendations. This framework has been adjusted to apply to the specific hazard of climate change (Kelman et al., 2009).

Also considering the hazard of climate change, an ongoing programme drawing on and extending these lessons is Many Strong Voices (MSV: www.manystrongvoices.org). The programme works with people from the Arctic (many of whom are islanders, such as from Greenland and Baffin Island) and SIDS to address climate change. At their own request, MSV brings them together to exchange knowledge about, and to devise approaches for dealing with, the climate change challenges that they face. In contrast to how climate 


\section{Islands}

change has mainly been addressed at the research (e.g. IPCC, 2007) and practice (e.g. the United Nations Framework Convention on Climate Change) levels, MSV's approach puts reducing greenhouse gas emissions (termed "mitigation" in climate change glossaries) in tandem with adjusting to the unavoidable impacts that climate change is bringing (termed "adaptation" in climate change glossaries).

That includes giving the peoples in the two regions a strong voice in international arenas such as the annual climate change negotiations, the research synthesis (e.g. IPCC, 2007), and the funds being promised for adaptation (Crump \& Kelman, 2009; Kelman, 2010). Participants in MSV include international organizations, government agencies, nongovernmental organizations, Indigenous Peoples' groups, research institutes, and community representatives from the Arctic and SIDS. They collaborate to pool their knowledge, wisdom, ideas, and actions. One such MSV activity is participatory action research to work with SIDS peoples to understand the islanders' interests in, vulnerabilities to, and adaptation approaches for climate change.

Beyond climate change, participatory action research has been used frequently on islands for other hazards. The studies by Cronin et al. (2004a, 2004b) were carried out on Pacific islands as a contribution towards using participatory action research for changing volcanology from a physical science field dominated by geologists to a more comprehensive investigation of volcano-people interactions.

Cronin et al. (2004a) worked on Ambae Island, Vanuatu. A volcanic crisis in 1995, which emergency managers had tried to resolve with top-down approaches, had ended up fermenting distrust between the local islanders and those from Port Vila and outside of Vanuatu. By working with the local islanders on their terms, and by respecting and combining different knowledge forms, Cronin et al. (2004a) developed guidelines and an alert system for dealing with future volcanic eruptions that were accepted by the local islanders and external participants.

Issues of trust also emerged in Haynes et al.'s (2008) study of Montserrat. They investigated who the Montserratians trusted in terms of accepting different forms of volcanic risk information and knowledge. Friends and family were trusted most, followed by scientists. Politicians and international media garnered little trust. The relative smallness and tightness of the population, often an island characteristic, was advantageous for the analysis and for subsequent action to improve the trust situation, because most of the parties involved had already met each other. In larger geographical areas, elected politicians have usually met only a small fraction of their constituents. Meanwhile, in larger geographical areas, scientists and civil servants might not need to meet many, or any, of the public whom they are trying to serve. That can lead to focusing on specific knowledge forms and one-way transfers of knowledge, neither technique of which necessarily fosters trust. 
On Savo in the Solomon Islands, Cronin et al. (2004b) critiqued participatory action research methods for implementing volcano-related disaster risk reduction based on different knowledge types. Through work in Honiara and on Savo, they tested and evaluated many tenets of participatory action research in order to factor in different perspectives and knowledge types. The biggest concern that they identified was ensuring representative participation, especially to cover both genders, all ages including youth, and all socio-economic classes since non-land owners are often left out.

Participatory action research was also used by Daly et al. (2010) on Samoa for combining knowledge types to deal with coastal hazards. The process was funded externally but was led by the national government, although based on local consultations in coastal villages through traditional practices. District meetings helped to integrate the highly localized perspectives for addressing district-wide topics that each village might not be able to connect with. The result was local coastal management plans integrated into a national coastal vulnerability reduction strategy. The consultation process was facilitated by external consultants, but was used as an opportunity to train national and local staff in participatory action research methods. The island context was important because the relatively small land area and population meant that the coastal management plans covered $100 \%$ of the country's coastline.

\section{Ecosystem-based disaster risk reduction}

One rapidly expanding area of participatory action research for dealing with disasters on islands is ecosystem-based disaster risk reduction. Much of this work, although certainly not all, emerges from island case studies.

An ongoing project is from the United Nations Environment Programme (UNEP): the Risk and Vulnerability Assessment Methodology Development Project (RiVAMP: UNEP, 2010). RiVAMP's method factors in environmental characteristics when analysing disaster risk and disaster vulnerability, explicitly accepting ecosystems as being important for disaster risk reduction, and including addressing climate change. The data collection approach covers externally acquired information as well as participatory action research with islanders. Both are combined to draw up an overall picture of risk and vulnerability on an island to present to policy makers and decision makers.

RiVAMP was developed mainly for applying to islands and coastal areas. For instance, one significant focus is vulnerability to tropical cyclones, with hazards such as storm surge, rainfall flooding, landslides, and winds - all potentially exacerbated by failure to deal with climate change (see also Shea, 2001, 2003). RiVAMP has so far been piloted in Jamaica (UNEP, 2010), with the island context chosen deliberately as best suiting the aims and objectives of the project and method. The reasons are the relative smallness and tightness of the island populations along with their dependence on natural resources from land-based and sea-based ecosystems. 


\section{Islands}

\section{Summary}

This section has provided examples of studies on participatory action research for dealing with disasters on islands. Some of the pioneering works from recent decades have been highlighted, especially those that factored island contexts and islandness into their work. Many others are available, but these examples illustrate the basis that exists to continue expanding participatory action research for dealing with disasters on islands-and to exchange lessons with non-island locations.

\section{Future Directions}

Equipped with a theoretical framework and rich examples from the previous sections, how does the island context and islandness contribute, or not contribute, to participatory action research for dealing with disasters? Three main points are suggested here emerging from the discussion above. First, improved use, understanding, and application or avoidance of the concepts and processes of vulnerability and resilience. Second, better addressing the relevance of scales. Third, a better understanding of the geographic context of islands.

\section{Vulnerability and resilience}

Numerous theories of vulnerability and resilience have emerged in the Western scientific literature over previous decades (e.g. see reviews by Gaillard, 2007, 2010; Lewis \& Kelman, 2010; Manyena, 2006). Few earlier authors connected these theories with theories of islandness (examples of exceptions are Campbell, 1984; Lewis, 1981) but recent work is starting to do so (e.g. Gaillard, 2007; Kelman \& Lewis, 2005; Mercer et al., 2009, 2010).

That work is indicating how theories of vulnerability and resilience might not always be appropriate for island contexts (also Baldacchino, 2004). Many indigenous island and nonisland languages do not have words for "vulnerability" or "resilience" while the concepts can be difficult to explain within those cultural contexts. That is, the words and concepts of "vulnerability" and "resilience" tend to be Western constructs, not always applicable or transferable to other cultures.

One notion related to vulnerability and resilience had a track emerging from Western science examining island case studies. It accepts and examines vulnerability as a long-term process, rather than as static characteristics that can be described as a snapshot in space and time (Lewis, 1984; Waddell, 1975). Vulnerability is not only about what a community sees around itself in the present state, but is also about what that community and external parties have done and plan to do to the community, its environment, and others over the long-term; why and how that has been done in order to reach the present state; and how changes might be effected to the present state in order to plan for and improve in the future (see also Lewis, 1999). Considering vulnerability as a long-term process through the past, present, and future, also applies to understanding resilience by examining the resilience process through the past, present, and future (Lewis \& Kelman, 2010). 
Despite island studies' contributions to vulnerability and resilience, does islandness contribute sufficiently to participatory action research for dealing with disasters? Perhaps it detracts from more fundamental theories of disaster and disaster risk reduction, namely those covering the vulnerability process and the resilience process? An example demonstrates how islandness does contribute to progress with understanding vulnerability and resilience.

Lewis \& Kelman (2010) further discuss that, from the perspective of vulnerability and resilience as processes, some difficulties emerge in some contemporary literature. IPCC (2007), the synthesis of climate change research, defines "vulnerability" and "resilience" to focus solely on one hazard, climate change, while interpreting the terms to focus on assessing the present state. These definitions set vulnerability science and resilience science backwards, especially by not fully accounting for past work on vulnerability and resilience that offers alternatives, such as the island-focused work referenced in this paper.

The island context has long illustrated that, when involving people in research, namely through participatory action research, separating society and ecosystems is unrealistic. Through island and disaster studies, the ground lost by IPCC (2007) in vulnerability science and resilience science needs to be, and could be, reclaimed. That might or might not entail avoiding the words "vulnerability" and "resilience" in order to connect with and assist islanders on their own terms and terminologies (e.g. Baldacchino, 2004). It could be that the specific context or case study will dictate how much the terms and explanations of "vulnerability" and "resilience" should be involved.

Further investigation would assist in determining how to best combine knowledge and wisdom types with respect to concepts of vulnerability and resilience - or the absence of those concepts. Such work would help to determine the suitability or otherwise of considering further how vulnerability and resilience could and should be introduced into cultures that lack those concepts. Additionally, that would indicate how some islanders' approaches for dealing with disasters without the concepts could and should be adopted outside of these islands.

\section{Scales}

The second main point of how island contexts and islandness contribute to participatory action research for dealing with disasters is with respect to scales. Islands are often local, national, and international at the same time, so they can show what happens when different scales are melded. Larger island and non-island countries often have large physical and metaphorical distances between different governance scales. For various single island jurisdictions, only one governance scale exists.

Disaster risk reduction tends to be premised on local initiative and action (e.g. Lewis, 1999; Twigg, 1999-2000; Wisner et al., 2004). Island governments often have little choice but to be local, helping to display the advantages and disadvantages of close to purely local approaches - as well as where external interventions could and could not assist. 
A self-contained closeness exists on small islands from which events and actions often impact on everyone. Kincaid's (1988: 52-54) description condenses as:

For the people in a small place, every event is a domestic event...eventually they absorb the event and it becomes a part of them, a part of who and what they really are, and they are complete in that way until another event comes along and the process begins again...To the people in a small place, the division of Time into the Past, the Present and the Future does not exist. An event that occurred one hundred years ago might be as vivid to them as if it were happening at this very moment.

Kincaid was born and spent her early life in Antigua which is governed with the much smaller island of Barbuda. It could be hard to have a single, locally-focused governance scale for all islands, because the coastline forms such a natural governance boundary that is often seen de facto, even if not de jure. Archipelagos are particularly interesting, in that the dispersion of their islands often creates problems of communication where outer islands are physically distant from the governance capital and/or main island. Tuvalu comprises 26 $\mathrm{km}^{2}$ of land area, dispersed over several inhabited atolls separated by linear distances of even hundreds of kilometres. The archipelagic characteristics of some island countries mean that disaster risk reduction governance includes islands of a few hundred people, or fewer, needing to deal with disasters with little or no immediate external assistance.

Nonetheless, the communities involved tend to have relatively small and isolated populations, which is an aspect of scale for islands that influences participatory action research for dealing with disasters. That makes it easier to talk to decision-makers, including heads of and participants in government - and even to involve them in the participatory activities.

The option of talking to leaders directly and including them in participatory activities should be grasped more often. Such interaction would contribute to understanding more about decision-making at different levels, the connections or lack of connections amongst decision-making at different levels, and the factors that support or inhibit scales being connected, especially where the populations they represent are geographically separated by their archipelagic nature.

How realistic is it to investigate all these aspects of scales and to apply the results, through participatory action research? Notwithstanding the successful case studies (e.g. Cronin, 2004a, 2004b; Daly et al., 2010; Maceda et al., 2009), what happens when the small, tight populations of islands lead to pettiness and patronage rather than collaboration and trust (e.g. Haynes et al., 2008)? Wider scales are not necessarily better for dealing with disasters, but that does not mean that wider scales are inevitably worse. The comparatively small scales of islands display both advantages and disadvantages for dealing with disasters. 
To demonstrate the challenges, a comparison can be made between absolute impact, with metrics being total fatalities or total monetary losses, and proportional impact, with metrics being the percentage of a population that becomes casualties or the percentage of assets that are lost. A good example is Montserrat. Montserrat's entire population before 1995 was half of the total death toll in Gujarat, India from the 26 January 2001 earthquake.

If only absolute impact were considered, then no calamity striking Montserrat could ever reach the scale of the Gujarat earthquake. Yet in 1995, when Montserrat's volcano started erupting, it severely affected $100 \%$ of Montserrat's population and nearly $100 \%$ of the island's infrastructure (e.g. Clay, 1999; Pattullo, 2000). A catastrophe that would affect $100 \%$ of India's population and infrastructure would be rare, showing that Montserrat's proportional vulnerability seems to exceed India's.

Despite over 15 years of volcanic activity on Montserrat, the death toll from immediate volcano hazards occurred on the same day, during the pyroclastic flows on 25 June 1997. At least 19 people died, a small number compared to the Gujarat earthquake. In considering proportional impact, that equates to over one million people being killed in a single disaster in India.

Similarly, the total economic damage of the 1995 Kobe, Japan earthquake has been estimated at over US\$130 billion. That represents more than 2,500 times the damage wrought by Cyclone Waka which swept Tonga in 2001. And yet, in relative economic figures, the impact of the Kobe earthquake was worth approximately $2.5 \%$ of Japan's GDP while Cyclone Waka had a much heavier impact on Tonga's economy, amounting to $36 \%$ of GDP.

That does not denigrate disasters in India or Japan, which exact a terrible toll in their own right. Absolute vulnerability and absolute impact have importance. Similarly, proportional impact and proportional vulnerability have importance (Lewis, 1979), also covering proportional resilience, so proportional metrics should be viewed alongside absolute metrics. Dealing with $100 \%$ of a population, of a country, and of infrastructure affected by a disaster presents its own challenges. The island context, such as Montserrat's situation, illustrates the importance of proportionality (see also Schneider, 1957). These island case studies inform other case studies, island and non-island, regarding how different governance scales understand and address disaster vulnerability over the long-term — or fail to do so.

\section{What is the relevance of islands?}

In focusing on participatory action research for dealing with disasters on islands, two of the three terms have been detailed: 'disasters' and 'participatory action research'. It is also legitimate to ask: What is the relevance of islands? The purpose of this question is not to revisit the extensive debates on defining islands (e.g. King, 1993; Streeten, 1993) but, rather, to delve deeper into the notion of islandness to determine whether or not it is legitimate to identify islands as an appropriate geographic entity to highlight. 


\section{Islands}

As a geographic entity for participatory action research for dealing with disasters, an island does work in some contexts, evidenced by the examples and references throughout this paper. Yet, many islands have been shown to be less connected internally or to be less coherent as a single entity (as also argued above).

Many islands can be difficult to traverse inland due to topography, jungle, or other natural features (e.g. PNG). With islanders frequently being more connected to the sea than to the land, it can be easier to connect with a nearby island across a short stretch of ocean than with another place on the same island (e.g. Boomert \& Bright, 2007). Without denying the value of single island studies, Terrell $(1999,2004)$ provides further discussion regarding geographies of island peoples across multiple islands compared to geographies of islanders on a single island.

Even where physical barriers do not exist on a single island, it does not necessarily yield a population with complete coherence. Barbados has a religious sect that isolates itself from the rest of the population, ostracizing members who seek outside influences. Many Melanesian islands are home to populations speaking different languages. They end up relatively isolated from each other, despite being on the same island. They prefer instead to embrace populations on other islands who speak the same or a similar language.

We have noted above how Samoans are dispersed around the world, which is typical of many islanders (e.g. Spickard et al., 2002). In countries comprising multiple islands, such as Tuvalu and Indonesia, residents of smaller islanders often migrate to larger islands, especially the capital city, as well as to centres overseas. Many Tuvaluans reside in Auckland, New Zealand, while many Indonesians have settled in Amsterdam, The Netherlands. That leads to multiple locations for islanders from a specific island, leading to a complex analysis of an island population.

As with Samoans, other islander expatriates tend to be well-connected to their island of origin, providing remittances that can also serve as emergency assistance. Morin \& Lavigne (2009) have noted this significance of disaster-related remittances, primarily from Marseille, France, for the Comoros. It might therefore be relevant and appropriate to involve expatriates in participatory action research for dealing with disasters on their island.

Consequently, should this paper refer to "island community" rather than to "island"? Perhaps. Two explanations are given for the choice of "island" rather than "island community". First, the arguments about defining an "island" and defining a "disaster" are contentious enough without adding yet another definition, that of "community" (e.g. Walmsley, 2006). Second, part of exploring islandness is the physical geography of islands, such as the small land-based resources as well as the isolation and connectedness generated by the sea. Discussing "island communities" necessarily entails considering islander connections beyond a specific piece of land. That dilutes the potential importance of confining discussion to a physical island, as has emerged to some degree through proportional impact, participatory mapping, and the need for local disaster-related endeavours. If, however, the degree of importance of a physical island is shown to be 
subsumed by the importance of a "social island" or "island community" - perhaps an "islander population" is more relevant than an "island population"- then that would be an important step forward for island studies.

From the evidence presented in this paper, the question remains open. Different forms of islands and different forms of island communities appear to have validity depending on context. Thus, the island context may matter for disaster-related research and action; depending on how that context is defined.

\section{Conclusion}

Steps can now be taken towards answering the research questions posed initially:

- In examining disaster research, island studies, and participatory action research, is anything gained through their combination?

- What value (if any) does island studies bring to participatory action research for dealing with disasters?

Three main points can be summarized from the critical analysis of material presented in this paper.

First, the material examined reaffirms that the island context can matter for participatory action research for dealing with disasters. Several strands have emerged due to islandness, such as the importance of proportionality in understanding disaster impacts, vulnerability, and resilience. As such, combining the areas of study has led to research insights that can have a useful impact on the ground for dealing with disasters. Does that mean that, in dealing with disasters, islands are a microcosm of a larger space, as many island and islandness studies intimate? The evidence from the studies presented is not clear enough to answer this question. Not enough detailed exploration has been made comparing different scales or in comparing island case studies with non-island case studies.

Second, islandness has much more to offer disaster-related research than is currently appreciated or used. Because islands tend to emphasize the local governance scale and are often isolated from external post-disaster aid, they have much to teach other geographies (at all scales) regarding how to approach dealing with disasters internally with limited external intervention. That covers emergency response and post-disaster recovery; but more importantly, it covers pre-disaster actions in order to avoid the need for emergency response and post-disaster recovery. Again, value is demonstrated in combining the three areas of study, especially in terms of introducing island studies to participatory action research for dealing with disasters. 


\section{Islands}

Nevertheless, parts of the two research questions remain open. Few studies have explicitly combined and balanced islandness theories with vulnerability and resilience theories. Consequently, material is unavailable to provide definitive statements regarding vulnerability and resilience originating from island characteristics, as distinct from other factors, and how that affects participatory action research for dealing with disasters.

Third, a solid science, policy, and practice basis exists regarding participatory action research for islands and islanders dealing with disasters (e.g. Journal of International Development, 2010; Shima, 2009). Nonetheless, more work is needed to study the links between (i) different theories (of islands, disasters, and participatory action research) and (ii) evidence found in the field on islanders' terms, especially regarding decisions that they take for their own actions to deal with disasters. That entails further exploring how and why islandness does and does not relate to dealing with disasters.

While the research questions are not answered fully, the work here has hopefully assisted in refining them, especially in pinpointing more focused enquiries. The objective of this paper has thus been met, in exploring the questions through a critical (but not comprehensive) overview of participatory action research for dealing with disasters on islands and in drawing some conclusions to guide further work.

One important element continually emphasized in disaster-related science, policy, and practice has, however, potentially been given short shrift through the research questions' focus on islands and islandness. That element is enacting long-term development processes that reduce vulnerability and reduce disaster risk, even if that is not the development processes' explicit purpose. Disasters have long been seen as a development concern (e.g. Lewis, 1977; UNDP, 2004) encompassing, amongst others, livelihoods, governance, education, and justice. The literature and practice suggest these approaches as being universal, irrespective of geographic context, in terms of principles, even if the geographic context necessarily influences the details of implementing these approaches. A more thorough exploration of islands as case studies for disasters as a development concern could reveal that islandness is not a primary consideration, except, perhaps, for islanders themselves. In theory, however, islandness might or might not be relevant for development principles regarding disasters.

As participatory action research seeks to deepen and broaden the answers to the questions raised, it is important to continue taking a critical approach to the work, always identifying the limitations while analysing the successes and areas for improvement. Participatory action research itself is far from being immune to criticisms and improvements, so it too should take account of its critics and propositions for overcoming the criticisms (e.g. Cooke \& Kothari, 2001; Hickey \& Mohan, 2004; McTaggart, 1997). Additionally, this paper has focused on islands in less affluent countries, with a notable emphasis on SIDS. Plenty of similar work is needed and is being carried out on islands in other countries, such as Norway (e.g. Thomassen et al., 2008). 
Extensions of the work presented here, and overcoming this work's limitations, will assist in developing more robust theories and practices for participatory action research for dealing with disasters on islands. That should help to better ensure that participatory action research does not become manipulative or carried out for its own sake but, rather, that the work is done on the islanders' terms, balancing internal and external influences, so as to help islanders deal with disasters.

\section{References}

Adams, J.E. (1978-1979) 'Union Island, West Indies: An Historical and Geographic Sketch', Caribbean Studies, Vol. 18, Nos. 3-4, pp. 5-45.

Ahlburg, D.A. (1991) Remittances and their Impact: A Study of Tonga and Western Samoa, Canberra, National Centre for Development Studies, Research School of Pacific Studies, Australian National University.

Anderson, M. \& Woodrow, P. (1989) Rising from the Ashes: Development Strategies in Times of Disasters, Boulder CO, Westview Press.

Angenheister, G. (1921) 'A Study of Pacific Earthquakes', New Zealand Journal of Science and Technology, Vol. 4, No. 5, pp. 209-231.

AOSIS (2009) Alliance of Small Island States Declaration on Climate Change 2009, New York, Alliance of Small Island States.

Aysan, Y. \& Davis, I. (eds.) (1992) Disasters and the Small Dwelling: Perspectives for the UN IDNDR, Oxford, James and James Science Publishers.

Baines, G.B.K. \& McLean, R.F. (1976) 'Re-Surveys of 1972 Hurricane Rampart of Funafuti Atoll, Ellice Islands', Search, Vol. 7, Nos. 1-2, pp. 36-37.

Baker, P.E. (1968) 'Petrology of Mt. Misery Volcano, St. Kitts, West Indies', Lithos, Vol. 1, No. 2, pp. 124-150.

Baldacchino, G. (2004) 'Moving away from the Terms Vulnerability and Resilience in Small Islands', Wise Coastal Practices for Sustainable Human Development Forum, Thursday, 11 March 2004, at 11:13 a.m., www.csiwisepractices.org/?read=490.

Baldacchino, G. (2006) 'Islands, Island Studies, Island Studies Journal', Island Studies Journal, Vol. 1, No. 1, pp. 3-18.

Belshaw, C. (1951) 'Social Consequences of the Mount Lamington Eruption', Oceania, Vol. 21, No. 4, pp. 241-253. 
Blake, B. (1993) 'Housing and Cyclones: Reducing Vulnerability of Samoan Fales', AODRO Newsletter, (Australian Overseas Disaster Response Organization), Vol. 11, No. 1, pp. 3-7.

Boomert, A. \& A.J. Bright (2007) 'Island Archaeology: In Search of a New Horizon', Island Studies Journal, Vol. 2, No. 1, 2007, pp. 3-26.

Campbell, J.R. (1984) Dealing with Disaster: Hurricane Response in Fiji, Honolulu HI, East-West Center.

Campbell, J.R. (2006) Traditional Disaster Reduction in Pacific Island Communities. GNS Science Report 2006/038, Lower Hutt, New Zealand, GNS Science.

Carr, L.J. (1932) 'Disaster and the Sequence-Pattern Concept of Social Change', The American Journal of Sociology, Vol. 38, No. 2, pp. 207-218.

Chambers, R. (1994) 'The Origins and Practice of Participatory Rural Appraisal', World Development, Vol. 22, No. 7, pp. 953-969.

Clay, E. (1999) An Evaluation of HMG's Response to the Montserrat Volcanic Emergency, DFID (Department for International Development) Evaluation Report EV635, London, DFID.

Comité d'Information Sahel (1975) Qui se nourrit de la famine en Afrique? Paris, F. Maspero.

Connell, J. \& Brown, R.P.C. (2005) Remittances in the Pacific: An Overview, Manila, Asian Development Bank.

Cooke, B. \& Kothari, U. (2001) Participation: The New Tyranny, London, Zed Books.

Copans, J. (ed.) (1975) Sécheresses et famines du Sahel, Paris, F. Maspero.

Cornwall, A. \& Jewkes, R. (1995) 'What is Participatory Research?', Social Science and Medicine, Vol. 41, No. 12, pp. 1667-1676.

Cronin, S.J., Gaylord, D.R., Charley, D., Alloway, B.V., Wallez, S. \& Esau, J.W. (2004a) 'Participatory Methods of Incorporating Scientific with Traditional Knowledge for Volcanic Hazard Management on Ambae Island, Vanuatu', Bulletin of Volcanology, Vol. 66, No. 7, pp. 652-668.

Cronin, S.J., Petterson, M.G., Taylor, P.W. \& Biliki, R. (2004b) 'Maximizing MultiStakeholder Participation in Government and Community Volcanic Hazard Management Programs; A Case Study from Savo, Solomon Islands', Natural Hazards, Vol. 33, No. 1, pp. $105-136$. 
Crump, J. \& Kelman, I. (2009) 'Many Strong Voices from Arctic and Island Peoples' in UNESCO (ed.), Climate Change and Arctic Sustainable Development, Paris, UNESCO, pp. 284-295.

Daly M., Poutasi, N., Nelson, F. \& Kohlhase, J. (2010) 'Reducing the Climate Vulnerability of Coastal Communities in Samoa', Journal of International Development, Vol. 22, No. 2, pp. 265-282.

Depraetere, C. (2008) 'The Challenge of Nissology: A Global Outlook on the World Archipelago. Part II: The Global and Scientific Vocation of Nissology', Island Studies Journal, Vol. 3, No. 1, pp. 17-36.

Duly, C. (1979) The Houses of Mankind, London, Thames and Hudson.

Firth, R. (1959) Social Change in Tikopia, New York, MacMillan.

Fritz, C.E. \& Mathewson, J.H. (1957) Convergence Behaviour in Disasters: A Problem in Social Control. Disaster Study No. 9. Washington DC, Committee on Disaster Studies, National Academy of Sciences - National Research Council.

Gaillard, JC. (2007) 'Resilience of Traditional Societies in Facing Natural Hazards', Disaster Prevention and Management, Vol. 16, No. 4, pp. 522-544.

Gaillard, JC. (2010) 'Vulnerability, Capacity, and Resilience: Perspectives for Climate and Disaster Risk Reduction', Journal of International Development, Vol. 22, No. 2, pp. 218232.

Gaillard, JC \& Maceda, E.A. (2009) 'Participatory 3-Dimensional Mapping for Disaster Risk Reduction', Participatory Learning and Action, Vol. 60, pp. 109-118.

Gaillard, JC \& Cadag, J.R.D. (2010) 'Participatory 3-Dimensional Mapping for Reducing the Risk of Disasters', poster presented at the $4^{\text {th }}$ Australasian Hazards Management Conference, 10-13 August 2010, Wellington, New Zealand. Available from: www.p3dmfordrr.com/P3DM_files/Gaillard\&Cadag_AHMC10_Poster.pdf

Gane, M. (1975) Report of a Mission to Assess the Hurricane Factor for Planning Purposes in Fiji. Bradford Disaster Research Unit Occasional Paper 9. Bradford, University of Bradford.

Global Network of Civil Society Organizations for Disaster Reduction (2009) 'Clouds but little rain...': Views from the Frontline - A Local Perspective of Progress towards Implementation of the Hyogo Framework for Action, Teddington, Global Network of Civil Society Organizations for Disaster Reduction. 
Haynes, K., Barclay, J. \& Pidgeon, N. (2007) 'Volcanic Hazard Communication using Maps: An Evaluation of their Effectiveness', Bulletin of Volcanology, Vol. 70, No. 2, pp. 123-138.

Haynes, K., Barclay, J. \& Pidgeon, N. (2008) 'The Issue of Trust and its Influence on Risk Communication during a Volcanic Crisis', Bulletin of Volcanology, Vol. 70, No. 5, pp. 605-621.

Hewitt, K. (ed.) (1983) Interpretations of Calamity from the Viewpoint of Human Ecology, London, Allen \& Unwin.

Hewitt, K. (1997) Regions of Risk: A Geographical Introduction to Disasters, Essex, Addison Wesley Longman.

Hewitt, K. \& Burton, I. (1971) The Hazardousness of a Place: A Regional Ecology of Damaging Events, Toronto ON, University of Toronto Press.

Hickey, S. \& Mohan, G. (eds.) (2004) Participation: from Tyranny to Transformation, London, Zed Books.

Hovey, E. (1903) 'The New Cone of Mont Pele and the Gorge of the Riviere Blanche, Martinique', American Journal of Science, Vol. 16, No. 94, pp. 269-281.

IPCC (2007) IPCC Fourth Assessment Report. Geneva, Intergovernmental Panel on Climate Change.

Journal of International Development (2010) 'Policy Arena on Climate, Disasters, and International Development', Vol. 22, No. 2, pp. 208-281.

Keesing, F.M. (1952) 'The Papuan Orokaiva vs. Mt Lamington: Cultural Shock and its Aftermath', Human Organization, Vol. 11, No. 1, pp. 26-22.

Kelman, I. (2010) 'Hearing local voices from Small Island Developing States for climate change', Local Environment, Vol. 15, No. 7, pp. 605-619.

Kelman, I. \& Lewis, J. (2005) 'Ecology and Vulnerability: Islands and Sustainable Risk Management', Insula: International Journal of Island Affairs, Vol. 14, No. 2, pp. 4-12.

Kelman, I., Mercer, J. \& West, J. (2009) 'Combining Different Knowledges: CommunityBased Climate Change Adaptation in Small Island Developing States', Participatory Learning and Action Notes, Vol. 60, pp. 41-53.

Kerr, J.S. (1976) Tropical Storms and Hurricanes of the South Pacific: Nov 1939-April 1969. Miscellaneous Publication No. 148, Wellington, New Zealand Meteorological Service. 
Keys, J.G. (1963) 'The Tsunami of 22 May 1960, in the Samoa and Cook Islands', Bulletin of the Seismological Society of America, Vol. 53, No. 6, pp. 1211-1227.

Kincaid, J. (1988) A Small Place, London, Virago Press.

King, R. (1993) 'The Geographical Fascination of Islands', in D.G. Lockhart, D. DrakakisSmith \& J.A. Schembri (eds.), The Development Process in Small Island States, London, Routledge, pp. 13-37.

Lane, S.N., Odoni, N., Landström, C., Whatmore, S.J., Ward, N. \& Bradley, S. (2011) 'Doing Flood Risk Science Differently: An Experiment in Radical Scientific Method', Transactions of the Institute of British Geographers, Vol. 36, No. 1, pp. 15-36.

Le Masson, V. \& Kelman, I. (2011) 'Disaster Risk Reduction on Non-sovereign Islands: La Réunion and Mayotte, France', Natural Hazards, Vol. 56, No. 1, pp. 251-273.

Lewis, J. (1977) 'A Primer of Precautionary Planning for (against!) Natural Disaster', Occasional Paper No. 13, University of Bradford, UK, Bradford Disaster Research Unit.

Lewis, J. (1979) 'The Vulnerable State: An Alternative View' in L. Stephens \& S.J. Green (eds.), Disaster Assistance: Appraisal, Reform and New Approaches, New York, New York University Press, pp. 104-129.

Lewis, J. (1981) 'Some Perspectives on Natural Disaster Vulnerability in Tonga', Pacific Viewpoint, Vol. 22, No. 2, pp. 145-162.

Lewis, J. (1984) 'Environmental Interpretations of Natural Disaster Mitigation: The Crucial Need', The Environmentalist, Vol. 4, No. 3, pp. 177-180.

Lewis, J. (1989a) 'Sea-level Rise: Some Implications for Tuvalu', Ambio, Vol. 18, No. 8, pp. 458-459.

Lewis, J. (1989b) 'Sea-level Rise: Some Implications for Tuvalu', The Environmentalist, Vol. 9, No. 4, pp. 269-275.

Lewis, J. (1990a) 'Small States Conference on Sea Level Rise', The Environmentalist, Vol. 10, No. 2, pp. 141-143.

Lewis, J. (1990b) 'Small States Conference on Sea Level Rise, Male, Republic of the Maldives, 14-18 November 1989’, Disasters, Vol. 14, No. 1, pp. 77-78.

Lewis, J. (1990c) 'The Vulnerability of Small Island States to Sea Level Rise: The Need for Holistic Strategies', Disasters, Vol. 14, No. 3, pp. 241-248.

Lewis, J. (1999) Development in Disaster-prone Places: Studies of Vulnerability, London, Intermediate Technology Publications (Practical Action). 
Lewis, J. and Kelman, I. (2010) 'Places, People and Perpetuity: Community Capacities in Ecologies of Catastrophe', ACME: An International E-Journal for Critical Geographies, Vol. 9, No. 2, pp. 191-220.

Maceda, E., Gaillard, J.C., Stasiak, E., Le Masson, V. \& Le Berre, I. (2009) 'Experimental Use of Participatory 3-Dimensional Models in Island Community-Based Disaster Risk Management', Shima: The International Journal of Research into Island Cultures, Vol. 3, No. 1, pp. 46-58.

Manyena, S.B. (2006) 'The Concept of Resilience Revisited', Disasters, Vol. 30, No. 4, pp. 433-450.

Marx, K. (1887) Capital: A Critique of Political Economy. Volume I Book One: The Process of Production of Capital, Moscow, Progress Publishers.

McCall, G. (1994) 'Nissology: A Proposal for Consideration', Journal of the Pacific Society, Vol. 17, No. 2-3, pp. 93-106.

McCall, G. (1996) 'Clearing Confusion in a Disembedded World: The Case for Nissology’, Geographische Zeitschrift, Vol. 84, No. 2, pp. 74-85.

McLean, R.F., Bayliss-Smith, R.P., Brookfield, M. \& Campbell, J.R. (editor H. Brookfield) (1977) The Hurricane Hazard: Natural Disaster and Small Populations, Island Reports No. 1, the UNESCO/UNFPA Population and Environmental Project in the Eastern Islands of Fiji, Man and the Biosphere Programme, Canberra ACT, Australian National University.

McTaggart, R. (ed.) (1997) Participatory Action Research: International Contexts and Consequences, Albany NY, State University of New York Press.

Mercer, J. (2010) 'Disaster Risk Reduction or Climate Change Adaptation: Are We Reinventing the Wheel?' Journal of International Development, Vol. 22, No. 2, pp. 247264.

Mercer, J. \& Kelman, I. (2008) 'Living with Floods in Singas, Papua New Guinea', in R. Shaw, N. Uy \& J. Baumwoll (eds.), Indigenous Knowledge for Disaster Risk Reduction: Good Practices and Lessons Learned from Experiences in the Asia-Pacific Region, Bangkok, United Nations International Strategy for Disaster Risk Reduction, pp. 46-51.

Mercer, J. \& Kelman, I. (2010) 'Living alongside a Volcano in Baliau, Papua New Guinea', Disaster Prevention and Management, Vol. 19, No. 4, pp. 412-422.

Mercer, J., Kelman, I., Suchet-Pearson, S. \& Lloyd, K. (2009) 'Integrating Indigenous and Scientific Knowledge Bases for Disaster Risk Reduction in Papua New Guinea', Geografiska Annaler: Series B, Human Geography, Vol. 91, No. 2, pp. 157-183. 
Mercer, J., Kelman, I., Taranis, L. \& Suchet-Pearson, S. (2010) 'Framework for Integrating Indigenous and Scientific Knowledge for Disaster Risk Reduction', Disasters, Vol. 34, No. 1, pp. 214-239.

Morin, J. \& Lavigne, F. (2009) 'Institutional and Social Responses to Hazards related to Karthala Volcano, Comoros. Part 2: The Deep-seated Root Causes of Comorian Vulnerabilities', Shima: The International Journal of Research into Island Culture, Vol. 3, No. 1, pp. 54-71.

Nunn, P.D. (2003) 'Nature-Society Interactions in the Pacific Islands', Geografiska Annaler, Vol. 85B, No. 4, pp. 219-229.

O'Keefe, P. \& Conway, C. (1977) Natural Hazards in the Windward Islands, Bradford Disaster Research Unit Occasional Paper 14. Bradford, University of Bradford.

O'Keefe, P., Westgate, K. \& Wisner, B. (1976) 'Taking the Naturalness out of Natural Disasters', Nature, Vol. 260, pp. 566-567.

Patterson, B.R. (1977) Geological Aspects of the Tonga Earthquake: 23 June 1977, Lower Hutt, New Zealand, Department of Scientific and Industrial Research.

Pattullo, P. (2000) Fire from the Mountain: The Tragedy of Montserrat and the Betrayal of its People, London, Constable and Robinson.

Prince, S.H. (1920) Catastrophe and Social Change, Doctoral Dissertation, Columbia University.

Rapoport, A. (1969) House Form and Culture, Englewood Cliffs NJ, Prentice-Hall.

Rousseau, J.J. (1756) 'Rousseau à François-Marie Arouet de Voltaire (Lettre 424, le 18 août 1756)', in R.A. Leigh (ed.) (1967) Correspondance complète de Jean Jacques Rousseau, Tome IV 1756-1757, Geneva, Institut et Musée Voltaire, Les Délices, pp. 37-50.

Schneider, D.M. (1957) 'Typhoons on Yap', Human Organization, Vol. 16, No. 2, pp. 1015 .

Shea, E. (2001) Pacific Island Regional Assessment of the Consequences of Climate Change and Variability (The Pacific Assessment), Honolulu HI, East-West Center.

Shea, E. (2003) Living with a Climate in Transition: Pacific Communities Plan for Today and Tomorrow, Honolulu HI, East-West Center.

Shima: The International Journal of Research into Island Cultures (2009) 'Special issue on Islands of Risk, Islands of Hope', Vol. 3, No. 1, pp. 1-97. 
Spickard, P.R., Rondilla, J.L., Hippolite \& Wright, D.H. (2002) Pacific Diaspora: Island Peoples in the United States and across the Pacific, Honolulu HI, University of Hawai'i Press.

Spillius, J. (1957) 'Natural Disaster and Political Crisis in a Polynesian Society: An Exploration of Operational Research', Human Relations, Vol. 10, No. 1, pp. 3-27.

Streeten, P. (1993) 'The Special Problems of Small Countries', World Development, Vol. 21, No. 2, pp. 197-202.

Terrell, J.E. (1999) 'Comment on Paul Rainbird, "Islands out of Time: Towards a Critique of Island Archaeology", Journal of Mediterranean Archaeology, Vol. 12, No. 2, pp. 240245.

Terrell, J.E. (2004) 'Island Models of Reticulate Evolution: The "Ancient Lagoons" Hypothesis' in S.M. Fitzpatrick (ed.) Voyages of Discovery: The Archaeology of Islands, Westport CT, Praeger, pp. 203-222.

Thomassen, J., Linnell, J.D., Follestad, A., Aarrestad, P.A., Jerpåsen, G., Risan, T. \& Harvold, K. (2008) Smølas framtid formes nå: Scenarioutviklingsseminar, Smøla 14-15, Report 376, Trondheim, Norsk Institutt for Naturforskning (NINA).

Twigg, J. (1999-2000) 'The Age of Accountability? Future Community Involvement in Disaster Reduction', Australian Journal of Emergency Management, Vol. 14, No. 4, pp. 51-58.

UN (1994) Report of the Global Conference on the Sustainable Development of Small Island Developing States. Document A/CONF.167/9 (October, 1994) from Global Conference on the Sustainable Development of Small Island Developing States. Bridgetown, Barbados, United Nations.

UN (2005) Draft Mauritius Strategy for the further Implementation of the Programme of Action for the Sustainable Development of Small Island Developing States. Document A/CONF.207/CRP.7 (13 January 2005) from International Meeting to Review the Implementation of the Program of Action for the Sustainable Development of Small Island Developing States. Port Louis, Mauritius, United Nations.

UNDP (2004) Reducing Disaster Risk: A Challenge for Development, New York, UNDP.

UNEP (2010) Risk and Vulnerability Assessment Methodology Development Project (RiVAMP), Linking Ecosystems to Risk and Vulnerability Reduction: The Case of Jamaica, Results of the Pilot Assessment, Geneva, United Nations Environment Program.

Waddell, E. (1975) 'How the Enga Cope with Frost: Responses to Climatic Perturbations in the Central Highlands of New Guinea', Human Ecology, Vol. 3, No. 4, pp. 249-273. 
Walmsley, J. (2006) 'The Nature of Community: Putting Community in Place', Dialogue, Vol. 25, No. 1, pp. 5-12.

White, G.F. (1942/1945) Human Adjustment to Floods: A Geographical Approach to the Flood Problem in the United States. Doctoral Dissertation, University of Chicago (1942) and republished as Research Paper No. 29 (1945), University of Chicago IL, Department of Geography.

Wisner, B., Blaikie, P., Cannon, T. \& Davis, I. (2004) At Risk: Natural Hazards, People's Vulnerability and Disasters, 2nd ed. London, Routledge.

Wisner, B., Stea, D. \& Kruks, S. (1991) 'Participatory and Action Research Methods' in E.H. Zube and G.T. Moore (eds.), Advances in Environment, Behaviour and Design: Vol. 3, New York, Plenum Press, pp. 271-295. 